\title{
Media as an environment of the modern patient and medical care institutions - management of communication in medicine - selected tools and marketing strategies
}

\author{
Alicja Łaska-Formejster
}

Katedra Socjologii Polityki i Moralności, Instytut Socjologii, Wydział Ekonomiczno-Socjologiczny, Uniwersytet Łódzki

Address for correspondence: Alicja Łaska-Formejster, Katedra Socjologii Polityki i Moralności, Rewolucji 1905 r. 41/43 90-214 Łódź, phone +48 693666 055, alicja.formejster@uni.lodz.pl

\section{Abstract}

Health communication, in the opinion of Tomasz Goban-Klas, is primarily a social practice in healthcare and a field for reflection and study. The changes occurring, at the semantic and at the tool level, result ever increasing interest of scientific circles', especially in issues included in the field of communication involving the new telecommunications media: digital, online, and mobile. This paper presents the selected levels of health communication, the medial activity of patients and medical institutions that fall within the area of analysis/social practice. The aim is to present selected concepts of medical marketing strategies and the changes occurring in the profile of the modern patient, with particular regard to the development of a technically oriented communication process. Changes taking place in the management of communication in medicine create new opportunities as well as threats. In addition, they initiate changes, which are not universally approved, in the course of interaction previously regarded as the model for contact between the patient and medical staff. Changes in the understanding of the relationships between the physician and the patient result, among others, in the creation of successive levels of communication, areas of activity and the means of reaching potential clients, as evidenced by the use of virtual space. This are is being annexed with an increasingly greater scope, hence its observation and analysis seem to be an extraordinary challenge for social scientists. An overview of the selected problem area has been based on a selective review, literature search and analysis.

Key words: medical communication, healthcare marketing, communication technologies, technology based communication tools, telemarketing

Stowa kluczowe: komunikacja w medycynie, marketing medyczny, internetowe technologie i narzęuzia komunikacyjne, telemarketing

Ministerstwo Nauki

i Szkolnictwa Wyższego
Przygotowanie do wydania elektronicznego finansowane w ramach umowy 641/ P-DUN/2018 ze środków Ministra Nauki i Szkolnictwa Wyższego przeznaczonych na działalność upowszechniającą naukę.

\section{Introduction}

In the mid twentieth century, Marshall McLuhan observed the influence of the new communication media, indicating that they are leading to significant social changes. Today, living in an environment with electronic media, it is impossible to ignore their role. Darin Barney emphasises that "the spirit of our age is the spirit of the network (...) the constitutive principles of the network have become the driving force of individual, social, economic and political life, and it distinguishes our period in history" [1]. Manuel Castells, when explaining 
the phenomena present in the modern network society, indicated that "networks constitute the new social morphology of our societies, and the diffusion of networking logic substantially modifies the operation and outcomes in the processes of production, experience, power, and culture". Information technology is bringing about major social and cultural transformation [2]. The expansion of the Internet has resulted in it encompassing activities that until relatively recently were typical for relationships and direct interactions, including communications [3]. The quality of the process of communication is an essential aspect of social interaction, on which the effectiveness and "efficiency" of inter-human relationships depend. This is of particular importance in the case of medical interactions in the physician-patient relationship. Meetings and discussions between the doctor and the patient directly influence the effectiveness of the medical assistance received by the patient. This has been proven as patients are more likely to give greater significance to the physician's personal characteristics and communication skills than to the professional skills, which they take for granted. When considering the behaviour of doctors, the patients pay attention, among others, to the degree of sensitivity to their needs and the social competences, such as the ease of communication [4].

As was shown by a pioneer of socio-medical analyses of the widely understood health issues - Magdalena Sokołowska [5] and her successors - the doctor alone, having positive attributes, could provide the effective remedy for the patient. An appropriate approach by the doctor to patients in the surgery makes it possible for patients to express themselves clearly and therefore easier for the doctor to diagnose the problem and select the appropriate method of treatment $[6,7]$. Recognising the significance of the process occurring during a physician-patient interaction to establish proper relationships, which include taking into account the subject matter, the context and respecting rights with an interdisciplinary and hybrid approach to human beings [8], is essential. Because of its significance in the diagnosis, the healing process and for creating a positive image of the institution, ever greater attention is being paid to the management strategies of medical institutions.

Transformation of the health care system in Poland, which started in the 1990 s, created the conditions necessary for the development of medical centres, which currently operate on market-based principles [9] and implement innovation [10]. Over the years, the quality of services offered in medical facilities, especially in the non-public/private sector, has changed and the scope has increased, although there are still many factors which make it difficult to gain access to them. They are not all able to cope with the growing demand for medical care, or meeting the appropriate quality for the proposed services and treatment, including the required degree of understanding of those receiving treatment. To a certain extent, these problems have led to changes in the behaviour of patients. Their decision-making process, regarding the choice of physician and institution, particularly when choosing to pay for medical care, is often preceded by a search for information about their medical condition, diagnostic and therapeutic methods, medical qualifications, the medical outlets, or even particular doctors. The change in the approach of patients, the recipients of medical services, has led, inter alia, to changes being introduced into the management of the health care system. Thus, the system is being adjusted to the needs of the patients and is leading to expectations to be gained from the implemented strategies, tools and marketing techniques [11]. Therefore, simultaneously with the transformations of the health care system, there are recognisable changes occurring in the profile of modern patients, in the legal nomenclature, the benefit recipients, or in the marketing nomenclature, the customers, who have to adapt to the changes involved in the increasingly technology-based, complex healthcare structure [12]. Consequently, it is possible to point out that systemic, organisational - including the technology-based process being implemented - and legal changes in the Polish health care system provide conditions for, or even initiate, changes in the patient's decision-making processes and health management activity. The aim of the paper is to present particular concepts of medical marketing strategies and the changes taking place in the profile of the modern patient, with special attention given to the development of a technologybased communication process. The overview is based on a selective review, a search and the analysis of literature.

\section{Selected aspects of medical marketing strategies targeting the communication process}

The development of modern medical technologies is having a significant impact on the changes occurring in the organisation of the healthcare system and in the patterns of health behaviour. The medicalisation of life [13-16]; the modernisation of the health care system [17]; the mass-media; and, thanks to the use of modern technology, the popularly available knowledge of medical characteristics, contributing to the development of a new secular vision of health and illness, are ushering in major changes in the strategies of medical marketing.

The first effects of marketing activities on the functioning of medical centres were described in English literature in the late 1960s. However, the concept of marketing activities of a medical character began to be introduced in the United States in the mid-1980s [18, 19]. In Poland, timid marketing activity began to develop in the 1990s, but has since developed and now plays an increasingly important role. Medical facilities are undergoing transformation and are adapting to principles of market operation by implementing modern management instruments. The successful implementation of the intended objectives is determined by the knowledge of the marketing environment, which is characterised by great dynamics of change [20]. This arises from the fact that its scope covers a wide area: policy (regulation), economics (competition), sociology, elements of technology, nature and demography $[21,22]$. What is undergoing a significant change is the approach to marketing, where an ever increasing role is being assigned to the issues of ethics, 
respect for the right approach to the environment and to individualism. Because of the dynamics of social and economic changes, the definition of marketing has been redefined by the American Marketing Association as, "(...) an activity, set of institutions and processes of creating, communicating, delivering, and exchanging offers of value to customers, receivers, partners, and the society as a whole" [23]. In marketing, there is a growing emphasis on the role of " $(. .$.$) communicating and delivering val-$ ues for the customers and managing customer relationships in a way that benefits the organisations and their stakeholders" [24]. It is pointed out that in the design of marketing processes, ever more attention is being paid to empathy, namely understanding the emotions of customers, and properly matching products and services to their needs [25], which in the case of activities of a medical character would appear to be of particular importance. Currently, however, the marketing of medical services is not perceived in terms of a classic promotion, but as an activity that falls within the scope of affiliate marketing, the marketing of a relationship, or social marketing, whose aims include, for example, supporting health promotion and education [26].

\subsection{Selected medical marketing strategies}

Marketing methods and tools are commonly used, especially in private medical institutions, one of them being Knowledge-based Customer Relationship Management (KCRM) methodology. This might be translated as a methodology for managing customer relationships, based on the diffusion of medical knowledge and medical coaching operating internally, meaning the diffusion of medical and managerial knowledge within a medical company, and externally, the diffusion of medical knowledge to a client [27]. It is also common to promote services, such as a promotion-mix concept, which includes: public relations, personal sales, sponsoriship, direct marketing tools and advertising. Another tool is Customer Experience Management (CEM), which focuses on tailoring a company's offer to people's lifestyles and their specific needs. It is important to properly identify all aspects of the customer's contact with a given outlet (or brand) and recognise the emotions aroused by the contact. The feelings experienced by the customer should be correctly identified by the company and given the same ranking as assigned to them by the customer. Specialists point out that it is particularly important - in relation to medical marketing - to properly undertake the so-called customer thinking operation, in order to understand the ranking that a client assigns to a particular service/product [28].

Philip Kotler additionally draws attention to two different concepts regarding the marketing objectives of a healthcare organisation: a transaction orientation, according to which the marketing goal is to obtain orders or to sell a product or service through the use of sales and advertising techniques, and a relationship orientation to develop a satisfying relationship with the customer [17]. In the context of this paper, more attention should be devoted to strategies that relate to the communication process, specifically directed at developing satisfactory relationships. One strategy is "personal sales" defined by the American Marketing Association as the process of informing and convincing customers to purchase a product/ service through personal contact in an exchange situation [29]. However, with regard to activities of a medical character, personal sales are defined as contact with the patients, whose satisfaction depends primarily on a skilful dialogue $[30,31]$. Satisfied patients constitute a facility's best showcase as information passed mouth to mouth is more convincing, which is reflected by a marketing principle: "(...) one dis-satisfied customer passes his opinion to ten, but a satisfied customer to only three" [32]. Thus, constructive communication is significant, as it plays an important role, not only as the basis for personal relationships created during a consultation, so influencing the course of the healing process, but also for enhancing the image of the doctor and that of the service provider.

The factors which influence the image created by the process of communication are particularly significant. Vitally important are aspects such as: focusing on the individual patient, not on the problem; the doctor's involvement with the patient; the doctor's behaviour as a humanitarian professional; showing more empathy; treating the patient with respect as a person; adopting the role of a 'patient teacher'; maintaining ties and listening to what the patient says $[4,33]$. The importance of the surroundings constitute another form of communication - conversation is not the only means of communicating with the patient - an environment adapted to the specificity of the contact also carries significant information, for example the appearance and atmosphere of the medical facility. The patient "absorbs" visual, auditory, olfactory and tactile signals [34] from the environment and assigns them due weight.

\subsection{The loyal customer and the decision-making process - emotional and social context}

An important role in forming the desired attitude of the benefit recipient, which can be defined as that of a "loyal client" $[35,36]$ is played by direct marketing activities of a social and intangible nature, such as personalisation of the customer, dialogue with the customer and the relationship with the customer. These actions are aimed at individualising the message and the offer, as well as directing it to a selected audience based on the demographic and social data collected in a database. Knowledge of the negative and positive expectations of a visit translates into an emotional reception, which is more intense than the experience and influences the patient's decisions, which are based on loyalty: loyal customers are often defined as the biggest assets of any business [37].

The emotion of the patient, as the benefit recipient, is one of the factors influencing the decision-making process. The patient, after encountering difficulties, for example at the pre-registration stage of a telephone conversation, may, if it is possible, stop seeking help from 
the particular facility and look for an alternative, which gives respect, cares about the comfort of a consultation and offers favourable conditions for conducting the appointment. As the modern patient is becoming increasingly more "mobile", the choice of a facility does not necessarily depend on its location. In addition, the process of shaping behaviour and the decisions of purchasers of medical services are influenced by:

- the social group to which the patient belongs (e.g. the family, circle of closest acquaintances and friends);

- a reference group, that is the group of people to which a patient wishes to belong in his everyday life, or - if he already belongs - wishes to be accepted (e.g. the community in the employing organisation);

- the opinion leaders (popular people in the media - who may be popular on a regional, national, or world scale);

- culture and past experience [27].

In the process connected with reaching decisions and shaping the emotions related to the expectations received from medical assistance, the manner of arriving at the decision to visit a doctor or the use of a particular medical service plays an important role. It may be impulsive (subjectively perceived necessity, ailments), habitual (regular follow-up visits), not routine (need for medical intervention), or prudent (preventive actions).

Therefore, in the field of health marketing, the subject of the activity is not so much, or only, a person in need of a particular form of support or medical help, but, perhaps above all the social subject driven by, among others, psychological and biological factors, social principles and the tools of persuasion. The patient's choice will be influenced by the application of well-established marketing rules, for example in the five-step purchase process: problem identification, information acquisition, information assessment, purchase decision and after-purchase behaviour [12]. Knowledge of the regulations, rules and the course of the decision-making processes facilitate the implementation of activities aimed at achieving such a high level of satisfaction so that the subject not only returns for more services, but also recommends the facility and the doctors to others [19]. The results of research show that money holds the same value as food or drink for a human being [38] and, therefore, health behaviour, concerning paid medical care is analysed in terms of its consumption - making purchases. Consequently, product promotions, price reductions, or "sales" will encourage patients to purchase the service.

It is significant that some marketing specialists oppose the use of such terms as "consumer" or "patient", because traditional and often stereotypical understanding of these words implies a passive attitude. However, modern consumers of medical services are often "producers" as they proactively share experiences, e.g. through the Internet, and they may independently guide a conversation with a doctor by presenting information and medical innovations found in the mass media. In conclusion, it can be assumed that the building of a long-term, valuable, mutual trust-based relationship with the customer has started to become the essence of marketing activities, although the real effects of these activities remain debatable.

\section{Changes in the manaagement of communication in medicine}

Referring to an earlier part of the paper, it would seem that there is no substitute for the "true", i.e. personal, holistic character of a patient's meeting with a doctor. However, making life dependent on computerisation and technology has meant that significant changes have occurred in this matter [39]. If reference is made to the model of a doctor-patient relationship, then the subject literature emphasises the change of nomenclature and points to a "new" approach in this type of relationship, corresponding to the strategies of direct marketing. It is becoming more and more common to depart from the paternalism of the Hippocratic tradition and focus on the autonomy and subjective treatment of the patient. In the bioethical literature, new, non-traditional relationship approaches are identified and new terminology, such as the legalistic model, which involves a physician and a client (legalistic model: physician-client); the economic consumer model, in which a physician meets a consumer (economic consumer model: physician-consumer) and is treated as the seller of medical products. The doctor is obliged to provide all information, listen to the wishes of the patient and uncritically accept his or her decision, even if it was not in line with the doctor's opinion based on medical knowledge or conscience. It is the patient who decides what is best for him or her. The next negotiation and contractual model is a relationship in which the doctor negotiates with the patient and concludes a kind of contract (negotiated contract model). The doctor and the patient conduct negotiations and these negotiatingcontractual procedures determine the understand something and, in the course of the negotiation, the doctor accepts the suggestion, it is a "good" solution. The last of the proposed models is the religious model, in which the relationship between a physician and a patient is treated as a moral and religious obligation [40].

Change in the relationship between the physician and the patient leads, among others, to the expansion of successive levels of communication, the areas of activity and the means of reaching potential customers, as evidenced by use of virtual space [41]. In mid-2016 the online world of Internet users consisted of more than 3.4 billion people, of whom more than 18 million are in Poland, who on average spend about 4.5 hours on computers and over an hour on mobile devices [42]. Additionally, it was estimated that by the end of 2016, the number of devices connected to the global network would be over 19 billion. In Poland it rose to 145.5 million in 2016 from 95.8 million in 2012. Consequently, in the process of the computerisation of societies, an increasing number of healthcare recipients long for ease and enhancement of their health activities. They are increasingly looking for ways to obtain knowledge and health services in virtual reality, resulting in the development of new communication channels employing Internet marketing.

There are over 800 Polish-language websites dealing with health, disease and drugs. The number of websites and the activity of users attest to the growing interest in, 
demand for, and popularity of medical information. The quality of information posted on health care portals varies and is often controversial. However, the Internet is currently the fastest growing communication and marketing channel and its merit, apart from efficiency and its high level of flexibility, is a measurable conducted activity.

E-marketing consists of a series of activities that employ the Internet to promote companies, to customise services and products to meet the needs of patients, or clients, and to meet the demands of the evolving market. The advances in modern technology enable the accomplishment of tasks, thanks to which the measurements of network activity are becoming more and more accurate, while the strategies employed are becoming increasingly adapted to the needs of the medical market. The basic tasks of Internet marketing relate to such activities as:

- website positioning and optimisation - increasing the chances of rapid selection by Internet users;

- email marketing, enabling communication with the customer by email - mailing should be carefully prepared, an address database acquired in accordance with good email marketing practices;

- the use of Google AdWords - the most widespread system of paid advertisements related to search engines;

- copywriting - allowing for the creation of advertisements and the publication of texts;

- viral marketing - creating a situation in which Internet users disseminate information related to activity of a particular company between themselves;

- on-line auctions related to the sale of a particular product using a specific auction platform [43].

Other tools used by medical facilities are Alexa Rank, a portal that gives a ranking of the most popular national and global websites, and Pingdom, which is used to evaluate the speed of a website. Internet monitoring may be conducted using the Google Alerts app, which makes it possible to obtain an opinion on given businesses, stores and selected products. It monitors events in the news, making it possible to collect up-to-date information on the competition and the sector. LegenHit allows one to identify people and the products they are looking for on monitored websites. Sotrender makes it possible to verify the best and worst content, it measures fan activities on a particular day and time on its fanpage and the activities of competing outlets [44].

Medical facilities are also eager to make use of readily available e-marketing tools such as Google Analytics, which facilitates tracking of traffic on any number of web pages, with the ability to generate over 80 different reports. This tool provides information on the number of visits, page views, and unique visitors to a particular website. It makes it easy to collect information about visitors to a given website, or how they arrived at it, either via a search engine, a link on another website, or typing an address in the browser bar. With Google Analytics, it is possible to determine the loyalty of individual visitors to a website, the time since their last visit, the duration of a visit to a website within individual partitions and the area of activity on the site in real time. Another tool is Google Trends, which analyses the search trends for individual keywords. Every day, over two million users search for health information using the Google search engine. The tool can assess the intensity of activity, for example, for flu, in different countries, regions, or at a particular time. It can also illustrate the effectiveness of advertising campaigns based on the increased inquiries about the promoted services or medical products.

\subsection{Patients in the process of medical communication}

In addition to being the target audience of marketing activities, patients are themselves willing to use the available technological innovations to control their health, using alternative means of communication. The market offers over 50,000 medical applications that can be easily installed on mobile devices, either for free or for a small fee. Such applications may be used for specialised diagnostics, for example skinScan, which enables the melanoma to be detected using a smartphone. Another mobile device, IDEAL LIFE Kiosk, measures blood pressure, weight, and blood glucose. Special lenses developed by Google in partnership with Novartis are also designed to test glucose levels. Another application, DrChrono, is operating in the US. Doctors can store a patient's complete medical file. With its help one can see what drugs are being taken by a patient and it can be used to arrange visits to a doctor or the necessary medical tests [45]. In the widely understood field of diagnostics, in Poland many tools have started to be used, for example InferMedicka, which is a company that has created a system that automatically makes diagnoses based on the symptoms described by the patient. The IfPolek portal facilitates checking the availability and prices of medicines in stationary pharmacies; the Harimata Company is developing an application to help in the early detection of developmental and behavioural disorders in children, including autism; DocPlanner, named Znany Lekarz in Poland, meets the need of patients wanting to know the opinions about doctors; Clinic Hunter is aimed at medical tourists and Konsult Expert provides information to those in need of a psychological consultation [46].

Patients are readily interested in the possibilities offered by technology advancement as it facilitates the monitoring of one's body and minimises the potential problems related to securing a personal medical consultation. However, in making use of an "impersonal" form of diagnosis, the implicit dangers and limitations should be taken into consideration. It should be remembered that the organism is a complex "mechanism" and the results so obtained, which are not always accurate as they do not include the compilation of factors affecting the overall condition of a patient, should be treated with the utmost caution. The inherent risk of putting personal information onto the Internet and its questionable security should not be forgotten.

Technological innovations also lead to a change in the perception of the model of the patient-doctor relationship. If the modern patient is referred to cyberspace, then

(...) a cybernetic patient would be happy to make an appointment for an on-line medical visit, to check the address of the 
chemist where the necessary medication could be remotely ordered and obtained and then take into consideration the medication warnings as well as taking advantage of health prevention programmes suited to the state of health [47].

Thus, digital media make it possible to create an exchange platform with the users [48].

It can be stated that the changes taking place in the process of medical communication have the ability to strengthen relationships, but also, as mentioned in the introduction, enable the patients to "independently determine" the initial diagnosis of their health, on the basis of their greater medical knowledge gained from on-online forums and medical portals (e-diagnosis). Health managers are increasingly talking about a new era for the patient - the empowered patient - jointly responsible for their own health through the acquisition of information and their enriched knowledge of diseases, healthy lifestyles and the means of moving around the increasingly complex structure of the healthcare system. Such a patient is better informed, "enriched" with knowledge and wishes to be a partner in the treatment process [49].

A "Polish empowered patient", empowered by knowledge and having increasingly higher expectation is creating an ever increasingly higher bar for the skills of medical staff and the ways in which medical institutions are managed. Such a patient increasingly wants to control his or her health online and manage it on-line. This patient is one who can define his or her needs within the consumer healthcare model and accepts responsibility for the actions and decisions taken. It is also a patient who, by being adept at using mobile communication equipment, wishes to engage in a dialogue with the doctor, or medical staff, during the consultation, initiating an interactive contact intended to develop a constructive relationship. Ever more frequently such a patient never switches off the mobile phone, uses the mobile Internet and mobile applications. This applied to more than $70 \%$ of the respondents [50].

The nature of virtual activity that changes the nomenclature of participants in medical interactions is worth noting. At present, there is talk of the electronic virtual patient and this is a concept related to interactive computer programs that simulate real patients and real clinical scenarios. Additionally, the term e-patient (electronic patient record, electronic health record) functions in two contexts: the first refers to electronic data on a specific patient that describe the overall health situation. The second refers to a person who uses the Internet to find health and medical information and should not be referred to as a patient, because it is not a disease that induces the internet activity [51]. For such people Consumers of health would be the best term as their actions could have prohealth and educational benefits.

\section{Conclusions}

Changes taking place in the profile of the modern patient, the expectations and perceptions concerning the scope and quality of medical care and the course of the communication process are, to a certain extent, illustrated by the online activities and the use of mobile communication tools. More than 12.6 million Poles [52] search for health information on the Internet, which indicates the great interest and demand for such information and offers huge opportunities for the use of new forms of communication to enhance health competencies. As mobile technologies "connect patients" and can build a new quality for the physician-patient relationship, they could enhance the comfort of the patient and result in a better personalisation of healthcare. This paper cites some examples of the tools used in the dynamically developing marketing sector. However, they are a good example of a planned strategy for improving the image of medical facilities and medical staff. The marketing tools can control the activity of modern patients and e-patients who are the beneficiaries of medical services. They provide evidence for the changes taking place at various levels of communication: the medical staff - the recipients of medical services, although analyses indicate [53], that many areas need further refinement, particularly in the public facilities of Health Care Centres [54]. Changes in the management of communication may result from the systemic needs, for example, related to requirements of the European Union; from the technological viewpoint, typically related to the use of applications on mobile devices; from the needs of today's individual patients who are ever more willing to take advantage of technological advancements. It is not only the physician-patient relationship that is changing, but all the elements that the relationship comprises, that co-form it. The language and mode of communication are changing, as is the nomenclature that had previously been reserved exclusively for medicine. Moreover, although considered unlikely in 2016 , it is believed that $55 \%$ of Poles will be arranging their doctor's appointments through the Internet by 2020 . This assumes that an integrated computerised program will be available. However, the risks associated with Internet activity should not be forgotten, as medical and managerial circles consider that there are some 'health risk' Poles, since " such patients are long on line and at the risk of charlatans and specialists using left-handed vitamins because real e-doctors are not available" [55]. It is worth recalling other aspects, which are the consequences of the development of new media and healthcare marketing strategies, such as the high probability of the 'beneficiaries' making irrational decisions as a result of the manipulative and persuasive strategies of communication and sales, which in the case of healthcare services appear to be ethically questionable. Another issue refers to Internet lobbying, since the new technology not only creates opportunities to reach patients, but also to model their health behaviour, which may often provide solutions inappropriate for their needs. In terms of ethics, the use of marketing tools in medical relationships is even more significant, as research shows that many decisions are made by patients subconsciously - a subject which is explored in the developing field of medical marketing known as neuro-marketing [56]. 


\section{References}

1. Barney D., Spoleczeństwo sieci, Wydawnictwo Sic!, Warszawa 2008.

2. Castells M., Spoleczeństwo sieci, PWN, Warszawa 2007.

3. Maj B., Media elektroniczne jako środowisko komunikacyjne współczesnego człowieka, in: Wawrzak-Chodaczek M., Jagoszewska I. (eds.), Komunikacja wobec wyzwań wspótczesności, Wydawnictwo Adam Marszałek, Torun 2011.

4. Nowina Konopka M., Komunikacja lekarz-pacjent. Teoria i pacjent, Instytut Dziennikarstwa, Mediów i Komunikacji Społecznej, Kraków 2016.

5. Sokołowska M., Socjologia medycyny, Państwowy Zakład Wydawnictw Lekarskich, Warszawa 1986.

6. Salmon P., Psychologia w medycynie wspomaga wspótpracę z pacjentem i proces leczenia, Gdańskie Wydawnictwo Psychologiczne, Gdańsk 2002.

7. Ostrowska A. (ed.), Socjologia medycyny. Podejmowane problemy, kategorie analizy, Wydawnictwo IFiS PAN, Warszawa 2009.

8. Janaszczyk A., Sobczak K., Gajewska M., Gtówne pojęcia konstytuujace perspektywe filozoficzno-społeczna $w$ naukach o zdrowiu, in: Janaszczyk A., Wengler L., Popowski P., Pietrzak P., Andrych-Brzezińska I., Adamska-Pietrzak E., Sobczak K., Bandurska E. (eds.), Filozoficzne, społeczne i prawne aspekty nauk o zdrowiu, Polskie Towarzystwo Programów Zdrowotnych, Gdańsk 2012.

9. Rozpędowska-Matraszek D., Nowe zarzadzanie kapitatem ludzkim w specjalistycznej opiece zdrowotnej, in: Depta A. (ed.), Zarzadzanie zdrowiem a problemy społeczeństwa obywatelskiego, Monografie PŁ, Łódź 2014.

10. Strzelecka A., Technologie informacyjne i komunikacyjne istotnym elementem przeplywu informacji w innowacyjnej działalności podmiotów medycznych, "Zeszyty Naukowe Politechniki Częstochowskiej, Zarządzanie” 2015; 19: 46.

11. Brzozowska-Woś M., Elektroniczne instrumenty komunikacji marketingowej w marketingu ustug medycznych, "Przedsiębiorczość i Zarządzanie" 2013, Wydawnictwo SAN Łódź; XIV (10): 31-40.

12. Mruk H., Marketing gabinetów lekarskich na rynku usług zdrowotnych, Wolters Kluwer Polska, Warszawa 2009.

13. Wieczorkowska M., Świat jako klinika. Medykalizacja życia w spoleczeństwie ryzyka biomedycznego, in: Gałuszka M. (ed.), Zdrowie i choroba społeczeństwie ryzyka biomedycznego, Wydawnictwo Uniwersytetu Medycznego w Łodzi, Łódź 2008.

14. Słońska Z., Nowe oblicze medykalizacji: redefinicja i marginalizacja promocji zdrowia, in: Piątkowski W., Płonka-Syroka B. (eds.), Socjologia i antropologia medycyny $w$ działaniu, Oficyna Wydawnicza Arboretum, Wrocław 2008.

15. Piątkowski W., Nowakowska L., System medyczny w Polsce wobec wyzwań XXI wieku. Perspektywa krytycznej socjologii zdrowia i choroby, "Przegląd Socjologiczny" 2012; LXI (2): 11-29.

16. Skrzypek M., Geneza i ewolucja podstawowych kategorii analitycznych socjologii medycyny, "Medycyna Ogólna i Nauki o Zdrowiu" 2012; 18 (4): 371-378.

17. Gałuszka M., Modernizacja systemu opieki zdrowotnej $w$ Polsce a problem komercjalizacji szpitali przez samorza- dy terytorialne, in: Gałuszka M. (ed.), Zdrowie i choroba $w$ społeczeństwie ryzyka biomedycznego, Wydawnictwo Uniwersytetu Medycznego w Łodzi, Łódź 2008.

18. Naidu G.M., Narayama Ch.L., How marketing oriented are hospitals in a declining market?, "Journal of Health Care Marketing" 1991; 1: 23-30.

19. Kotler Ph., Shalowitz J., Stevens R.J., Marketing strategiczny w opiece zdrowotnej, Wolters Kluwer, Warszawa 2011.

20. Nowicka K., Rola pacjenta w procesie podejmowania decyzji konsumenckich, „Marketing i Rynek” 2004; 7: 21-25.

21. Kotler Ph., Armstrong G., Saunders J., Wong V., Marketing. Podręcznik europejski, Polskie Wydawnictwo Ekonomiczne, Warszawa 2002.

22. Martin D., Schouten J., Sustainable Marketing, Prentice Hall, New Jersey 2012.

23. AMA - Amerykańskie Stowarzyszenie Marketingu; www. marketingpower.com/aboutama/pages/definitionofmarketing.aspx. (accessed: 03.06.2017).

24. Maclaran P., Saren M., Stern B., Tadajewski M. (eds.), Marketing Theory, Sage Publications, London 2010.

25. Kotarbiński J., Czas na rewolucję w marketingu, in: Gruszka A. (ed.), Raport. Nowa rola marketingu, Instytut Badawczy IPC, Wrocław 2016: 3.

26. Syrkiewicz-Świtała M., Holecki T., Kotowski P., Koncepcja marketingowego zarządzania organizacją świadczaca ustugi medyczne, "Zarządzanie i Edukacja” 2012; 81: 43-56.

27. Perechuda K., Kowalewski M. (eds.), Zarzadzanie komercyjna firma medyczna, Wydawnictwo Kluver, Warszawa 2008.

28. Maciorowski A., Lobbing rośnie w sitę, "Marketing w Praktyce" 2004; 3: 41.

29. Mullin R., Sales Promotion. How to Create, Implement \& Integrate Campaigns that Really Work, $5^{\text {th }}$ ed., Kogan Page, London 2010.

30. Barska A., Śnihur J., Istota marki jako element przewagi konkurencyjnej i zachowania tożsamości, in: Rosa G., Smalec A. (eds.), Marketing przyszłości. Trendy. Strategie. Instrumenty. Wspótczesne wyzwania komunikacji marketingowej, “Zeszyty Naukowe Uniwersytetu Szczecińskiego. Ekonomiczne Problemy Usług” 2009; 42: 235.

31. Ruta A., Marketingowe zarządzanie placówka medyczna, "Przegląd Naukowo-Metodyczny. Edukacja dla Bezpieczeństwa" 2014; 2: 165-172.

32. Olesch A., Ludzka twarz ochrony zdrowia, "Ogólnopolski System Ochrony Zdrowia” 2012; 10: 11.

33. Wróblewska I., Steciwko A., Zaufanie jako jeden z najistotniejszych czynników umożliwiających prawidłowe porozumiewanie się pomiędzy lekarzem a pacjentem, in: Barański J., Steciwko A. (eds.), Relacja lekarz - pacjent, Edra Urban \& Partner, Wrocław 2013.

34. Bukowska-Piestrzyńska A., Marketing ustug zdrowotnych, od budowania wizerunku placówki do zadowolenia klientów, Wydawnictwo CeDeWu, Warszawa 2007.

35. Wilmańska-Sosnowska S., Lojalność jako kategoria wspótczesnego marketingu, in: Sobczyk G. (ed.), Współczesny marketing. Trendy. Działania, PWE, Warszawa 2008.

36. Kozielski R., Partner czy zwierzyna łowna?, "Marketing w Praktyce" 2010; 3: 20-24. 
37. Stopczyńska K., Wplyw wizerunku kreowanego za pomoca social media na kreowanie postaw lojalnościowych klientów, "Marketing i Rynek" 2014; 11: 270.

38. Zweig J., Twój mózg, twoje pieniądze, Wydawnictwo Laurum, Warszawa 2008.

39. Łaska-Formejster A., Pacjent w sieci zależności. Spoleczny kontekst praw i autonomii pacjenta, Wydawnictwo Uniwersytetu Łódzkiego, Łódź 2015.

40. Biesaga T., Autonomia lekarza i pacjenta a cel medycyny, "Medycyna Praktyczna. Psychiatria" 2008; 2; http://www. mp.pl/etyka/index.php?aid=26784\&_tc=B55F5774FC6 FBFBFE3D0AD56E0924A60 (accessed: 04.12.2016), za: Donovan D.K., The physician-patient relationship, in: Thomasma D.C., Kissell J.L. (eds.), The health care professional as friend and healer, Georgetown University Press, Washington 2000.

41. Laska-Formejster A., Nowoczesne technologie komunikacyjne w systemie opieki zdrowotnej. E-narzędzia i pacjent doby "empowered" a etos zawodu lekarza, "Humanizacja Pracy” 2014; 2 (276), XLVII: 187-202.

42. Raport 2016. Polskie badania Internetu. Internetowe serwisy o zdrowiu; https://www.google.pl/\#q=\%C5\%BCe+pona $\mathrm{d}+88 \% 25+$ internaut $\% \mathrm{C} 3 \% \mathrm{~B} 3 \mathrm{w}+$ +poszukuje $+\mathrm{w}+$ sieci + info rmacji+o+zdrowiu+ (accessed: 01.06.2017).

43. Heuristic, 6 najbardziej popularnych narzędzi do e-marketing $u$; http://www.heuristic.pl/blog/e-marketing/96.html (accessed: 04.04.2017).

44. Kuźma M., Skuteczne narzędzia e-marketingowe, "Ogólnopolski System Ochrony Zdrowia” 2012; 10: 25-26.

45. Niklas J., Zdrowie w "rękach" aplikacji, 2015; https:// panoptykon.org/wiadomosc/zdrowie-w-rekach-aplikacji (accessed: 29.05.2017).

46. Najlepsze polskie start-upy medyczne; https://www.forbes. $\mathrm{pl} /$ pierwszy-milion/najlepsze-polskie-start-upy-medyczne-2017-raport-gdziepolek/53q8p8k (accessed: 01.08.2017).
47. Wojnarowicz-Głuszek B., Jakość w e-zdrowiu, "Ogólnopolski System Ochrony Zdrowia OSOZ” 2012; 10: 27.

48. Rakić B., Rakić M., Integrated marketing communications paradigm in digital environment: the five pillars of integration, "Megatrend Review" 2014; 11 (1): 187-203.

49. Łaska-Formejster A., Pacjenci ery empowered wyzwaniem dla nowych form zarzadzania i strategii marketingowych w ochronie zdrowia, in: Depta A. (ed.), Zarzadzanie zdrowiem a problemy spoteczeństwa obywatelskiego, Monografie Politechniki Łódzkiej, Łódź 2014.

50. Wykorzystanie aplikacji mobilnych, Raporty na temat MHEALTH; http://www.new.medutools.pl/raporty-na-temat-mhealth/ (accessed: 14.09.2017).

51. Gałuszka M., Nowe zjawiska $w$ relacji lekarz-pacjent w kontekście rozwoju internetu, "Przegląd Socjologiczny" 2012; LXI (2): 145.

52. Raport 2016. Mobile $i$ digital w Polsce $i$ na świecie w 2016 r.; https://mobirank.pl/2016/01/27/mobile-digital-w-polsce-na-swiecie-2016/ (accessed: 25.05.2017).

53. Zalewska-Turzyńska M., Zintegrowana komunikacja marketingowa $w$ ustugach zdrowotnych, "Przedsiębiorczość i Zarządzanie”, Wydawnictwo SAN, XIV (10), Łódź 2013: 41-51.

54. Ustawa z dnia 30 sierpnia 1991 r. o zakładach opieki zdrowotnej, Dz. U. 2007 r. Nr 14 poz. 89, z późn. zm.; http:// isap.sejm.gov.pl/DetailsServlet?id=WDU19910910408 (accessed: 09.06.2017).

55. Leśniewski B., Mamy już e-pacjentów i e-szarlatanów. Dramatycznie brakuje e-lekarzy; https://www.termedia.pl/ mz/Mamy-juz-e-pacjentow-i-e-szarlatanow-Dramatycznie-brakuje-e-lekarzy,27583.html (accessed: 20.09.2017).

56. Zaltman G., Jak myśla klienci. Podróż w głąb umystu rynku, Dom Wydawniczy Rebis, Poznań 2008. 